\title{
Erratum to: Reusing enterprise models to build platform independent computer models
}

\author{
Verónica $\operatorname{Pazos}^{1} \cdot$ Ricardo Chalmeta ${ }^{1}$
}

Published online: 11 February 2017

(C) Springer-Verlag Berlin Heidelberg 2017

\section{Erratum to: Inf Syst E-Bus Manage \\ DOI 10.1007/s10257-016-0307-x}

In the original publication of the article, the author names were incorrect. The correct names should be:

Verónica Pazos, Ricardo Chalmeta.

The original article was corrected.

The online version of the original article can be found under doi:10.1007/s10257-016-0307-x.

Ricardo Chalmeta

rchalmet@uji.es; rchalmet@1si.uji.es

Verónica Pazos

verocorella@gmail.com

1 Grupo de Investigación en Integración y Re-Ingeniería de Sistemas (IRIS), Departamento de Lenguajes y Sistemas, Universitat Jaume I, 12006 Castellón, Spain 